\title{
The socio-political ties of expert bodies. How to reconcile the independence requirement of reliable expertise and the responsiveness requirement of democratic governance
}

Eva Krick - ARENA Centre for European Studies, University of Oslo, Norway (eva.krick@arena.uio.no)

Cathrine Holst - Department of Sociology and Human Geography and ARENA Centre for European Studies, University of Oslo, Norway (cathrine.holst@sosgeo.uio.no)

Published by European Politics and Society (DOI:10.1080/23745118.2018.1515866)

\begin{abstract}
This study questions the traditional story of the detachment and independence of expert bodies such as agencies, central banks and expert committees. It shows that there are numerous institutional links with elected bodies and societal actors that we typify as mechanisms of stakeholder inclusion, government control and public and parliamentary scrutiny. With reference to EU examples, we illustrate that these socio-political ties are intensifying and attend to the normative implications of this 'representative turn'. When expert bodies increasingly link up with societal and political actors, this can be a source of democratisation, but it can also politicise and undermine the independence of expertise. Against this background, the key question becomes how to reconcile the independence requirement of reliable expertise and the responsiveness requirement of democratic governance. We approach this question by, first, delineating a way of incorporating ideal and non-ideal concerns in normative assessment. Second, we identify the key normative challenges related to the legitimate role of experts in democracies and discuss institutional solutions to the 'democratic-epistemic divide' that strike a balance both between the two norms, and between ideal requirements and feasibility constraints.
\end{abstract}


Keywords: expert bodies; non-majoritarian institutions; EU governance; sociopolitical ties; representative turn; normative assessment

\section{Introduction}

The background of the study at hand, and the special issue it concludes, is the millennia-old tension between the rule of knowers and democratic rule, the tension that lies essentially in the specialisation and independence logic of reliable expert knowledge and the equality and inclusion imperative of democracy. ${ }^{1}$ This democratic-epistemic divide or 'dilemma of expertise' (Nowotny, 2001) has been exacerbated by modern society's growing dependency on expertise for solving increasingly complex and technical collective problems (Holst \& Molander, 2017; Turner, 2013) and by the legitimacy crisis of the representative model of democracy (Saward, 2010). ${ }^{2}$ We focus on the democratic-epistemic divide as it manifests itself in the political role of expert bodies such as regulatory and executive agencies, nondepartmental public bodies, advisory boards and committees or independent central banks. ${ }^{3}$ Specialised knowledge and organisational autonomy is key to the authority of these institutions (Busuioic, 2009; Carpenter, 2010; Vibert, 2007, p. 4).

1 We define expert as a social status that is attributed to a person who is considered more knowledgeable than others on a certain issue.

2 We define expertise as the knowledge claims of experts that have advisory, guiding, instructing character and that are of particular relevance in the policy context where they inform and shape collective decisions ('policy expertise').

3 An expert body here refers to a norm-setting or advising public body, the authority of which builds chiefly on the specialised knowledge of its participants/staff, who are neither elected nor directly steered by governments. 
Yet, they are not academic, knowledge-producing institutions, but part of the system of government in the wider sense. They exert formal and/or de facto public authority and are set apart or only loosely tied to elected institutions. Some operate at arms' length from governmental control; some are even further detached. Across countries and within political systems, there is a large variety of empirical forms and terminology. With slightly different emphases, these boundary institutions at the policy-science-nexus have also been termed 'non-majoritarian institutions' (Thatcher \& Stone Sweet, 2002), 'quasi-autonomous (non-governmental) organisations' (quangos) (Greve, Flinders \& van Thiel, 1999) or 'unelected bodies' (Vibert, 2007) in the literature. ${ }^{4}$ These institutions stand for the rise of the regulatory, de-politicised state and the empowerment of experts and technocrats (Thatcher \& Stone Sweet, 2002), and their 'explosion' in recent decades has been connected to 'the tidal wave of bureaucratic reorganisation known as New Public Management (NPM)' (Greve et al., 1999, p. 130). They have also been interpreted as the epitome of expertisation (or 'scientification') trends, i.e. the increasing reliance on science, evidence and expertise in modern policy-making (Gornitzka \& Krick, 2018; Holst \& Molander, 2017; Turner, 2013), and their relative independence is

4 Non-majoritarian institutions are defined by Thatcher and Stone Sweet (2002, p. 2) as 'those governmental entities that (a) possess and exercise some grant of specialised public authority, separate from that of other institutions, but (b) are neither directly elected by the people, nor directly managed by elected officials'. In Vibert's words, unelected bodies 'a) exercise official authority but are not elected or headed by elected official and are b) deliberately set apart or only loosely tied to elected institutions' (Vibert, 2007, p. 4). Greve et al. (1999, p. 130) understand quangos as 'organizations which spend public money and fulfil a public function, but exist with some degree of independence from elected politicians', which includes executive agencies, 'non-departmental public bodies', public expert committees, and even state-owned corporations and NGOs. 
both a source of their authority and a matter of concern from a perspective of democratic accountability (see e.g. Curtin, 2007; Holst \& Molander, 2017). Their prevalence has triggered a new research field within public administration studies, which has traced the rise of these institutions not only on the EU level, but also within nation states (see e.g. Busuioc, 2013; Christensen \& Holst 2017; Curtin 2007, 2017; Egeberg, Schaefer \& Trondal, 2003; Egeberg \& Trondal, 2011; EnnserJedenastik, 2015; Gornitzka \& Krick, 2018; Kelemen, 2002; Lord, 2011). Recently, research on these institutions has directed more attention to the social and political ties of expert bodies (Busuioc, 2013; Ennser-Jedenastik, 2016; Gornitzka \& Krick, 2018; Lodge, 2008; Pérez-Durán, 2017), i.e. institutions that link up these expert bodies to civil society or the political realm (see section 1 ). Such institutional links can strengthen accountability relationships and thus add to the responsiveness and legitimacy of expert-based decision-making. However, a representative turn of expert bodies towards elected governments and parliaments as well as non-elected forms of representation through association, can also politicise and undermine the independence of the developed expertise, which has been described as one of the main sources of trustworthiness and problem adequateness of expert judgements (Haas, 2004; Lentsch \& Weingart, 2011) (see section 3).

This double challenge affects the normative questions that need to be dealt with. The key question is not only how the power of detached expert bodies can be kept in check by democratic means, or how their autonomy can be ensured, but how to strike a balance between the independence requirement of reliable expertise and the responsiveness requirement of democratic governance.

In the following, based on the contributions to this special issue on the social ties of 
non-majoritarian institutions (or expert bodies), as well as on existing research and official documents, we summarise, first, empirical varieties of expert bodies' institutional links with the societal and political realm. We distinguish between three types of ties (government control, stakeholder inclusion, parliamentary and public scrutiny) and three types of expert bodies that play a pronounced role across Europe (agencies, central banks and advisory committees) (section 1). With reference to empirical examples on the EU level we can show that the most quintessential expert bodies in European policy-making (decentralised agencies, expert groups, comitology committees and the European Central Bank (ECB)) are clearly, and increasingly, socially and politically embedded and scrutinised even when they have a large degree of discretion. Against this background, the perception of expert bodies as detached, depoliticised and technocratic needs to be refined and the normative questions raised need to be adapted to this reality.

Second, after this mapping, typification and (re-)conceptualisation of European expert bodies, we discuss different ways to approach the identified empirical patterns from a normative perspective (section 2). There is a set of pitfalls to be avoided in such an endeavour, and we delineate a way of balancing ideal and nonideal concerns. Our approach is to utilise the considerable proximity between ideal theory parameters and the normative concerns identified within empiricallygrounded research on expert bodies.

On this basis, we, third, elaborate on the normative implications of socio-political ties of expert bodies (section 3). We discuss the foundations of independent, largely impartial expertise on the one hand and democratised, accountable expertise production on the other. We explore the boundaries and tensions between these two normative dimensions and suggest institutional solutions to the tension that are 
neither too idealised to be applicable in practice, nor bound by immediate constraints to an extent that they fail to provide a critical corrective. For this, we build in part on ideal theory-oriented normative political theory, in part on empirically grounded, non-ideal theorising in social science.

\section{Varieties of socio-political ties: empirical mapping and typification}

In the following, we distinguish between three forms of expert bodies' sociopolitical ties: stakeholder inclusion (1.1.), executive control (1.2.) and parliamentary and public scrutiny (1.3.). There is a wide variety of empirical forms of expert bodies, with considerable differences both between and within politicaladministrative systems. When not otherwise stated, our examples of 'agencies', 'independent central banks' and 'advisory committees' here refer to EU level 'decentralised agencies', the ECB model, 'expert groups' and 'comitology committees'.

Regulatory agencies such as the currently 33 decentralised agencies of the EU have their own legal personality and basis. They are staffed with civil servants and provide advice and public services, perform operational activities, adopt binding decisions and implement key tasks. Advisory committees such as expert groups and comitology committees have formally a merely advisory character. Expert groups can advise on policy formulation or implementation, are often established by decree, seated within a Directorate General of the EU Commission (Commission) and primarily composed of interest group representatives, academic experts and member state civil servants (Gornitzka \& Krick, 2018). Comitology committees are dominated by member state representatives, established by law and deal with draft implementing measures sent to them by the Commission. Whether they are placed 
outside or within the Commission's administration and to which degree they are autonomous is contested (see Curtin, 2007). The ECB is an official EU institution that was established by a constitutional act. It takes authoritative, autonomous decisions and adopts binding regulations in monetary policy. The ECB is extraordinarily independent and not allowed to seek or take instructions from any other institution. These organisational differences have implications for the institutions' discretion, independence and accountability as well as the status of their members and staff. Yet, one should not overestimate the power of formal rules. After all, delegation analysis has shown that the most formally autonomous agencies are often controlled and politicised informally, through the backdoor (Busuioc, 2009; EnnserJedenastik, 2015) and with regard to comitology committees, Curtin points out that 'in practice it appears that the Commission almost never differs from the opinion of the committee' (Curtin, 2007, p. 529; see also Egeberg, Schaefer \& Trondal, 2003). The following subsections each start with a general account of the empirical varieties of the respective types of socio-political ties that the subsection focuses on. This is followed by an empirical account of the state of affairs and recent developments for the cases of the ECB, the EU's decentralised agencies, comitology committees and expert groups.

\section{Stakeholder inclusion}

Even the most detached expert bodies link up with stakeholders - comprising here political parties, NGOs and interest groups - to a certain extent. However, the degree of formalisation of relations and the roles of stakeholders vary considerably. Stakeholders can participate as co-deciders or advisors, they can observe and listen, or voice their concerns in a one-sided relationship (Bader, 2014). Some expert 
bodies consult interest groups and NGOs informally and on an ad hoc basis within loosely attached hearings or participatory formats. Some have permanent stakeholder panels or reference groups whose input is officially channelled into the decision process. Others include representatives of political parties, constituent states or interest groups into oversight boards and yet other expert bodies elevate stakeholders to the rank of 'expert' by involving them as equal members or part of the staff of an expert body (see Krick, this issue; Bader, 2014).

Despite the often evoked demise of corporatism, there is scattered evidence of stakeholders asserting themselves as important members of the EU's expert groups with interest groups adapting to expertisation pressures by professionalising internally and using information as 'access goods' to the policy process - instead of being crowded out by academics (Bouwen, 2004; Gornitzka \& Krick, 2018; see also Hesstvedt \& Christensen, this issue). As part of the EU's common approach on decentralised agencies ${ }^{5}$ and in response to 'technocracy' allegations, nearly half of the EU's agencies now involve societal representatives within management boards, distinct stakeholder groups or expert committees (Pérez-Durán, 2017) and agencies such as the European Medicines Agency and the European Chemicals Agency have recently strengthened their ties with civil society through consultation and hearing channels. Public administration studies also describe a growing 'partypoliticisation' of the most formally independent European regulatory agencies, with politicians responding to increasing degrees of agency independence with greater efforts to install political allies within agency leadership (Ennser-Jedenastik, 2015; see also Busuioc, 2013; Lodge, 2008). Even the ECB links up with stakeholders 
through a range of 'advisory groups' that represent financial corporations, companies and (trade) associations alongside national central banks. ${ }^{6}$

\section{Executive control}

All types of expert bodies underlie executive influence to certain extents. Governments can use their discretion vis-à-vis advisory committees in terms of composition and mandate (Krick, 2015). Governments can link up with agencies through seats in management boards or through evaluation and reporting requirements to the executive and they can use legal means to change the rights of expert bodies. Governments can furthermore contribute to strengthening the sociopolitical ties of these bodies by embracing their expertise, incorporating their output into their own political strategies and explaining it to the public (see Landwehr \& Wood, this issue). While this may infringe on the autonomy of expert bodies, it can add to their accountability since it establishes a visible link between elected politicians and the expert body.

Although the independence of the ECB is protected to an extraordinary degree against political interference, the financial crisis underlined that its decisions are de facto restricted in particular by the EU's creditor countries. The autonomy of European decentralised agencies has lately been balanced by the strengthening of agencies' management boards that are dominated by directors of national agencies and Commission representatives, by expanded executive evaluation, monitoring and auditing competences and the agencies' extended reporting requirements

6 Corporate Europe Observatory (2017) lists 22 such advisory groups in October 2017 and points to the 'corporate bias' of these groups. 
(Curtin, 2007; Egeberg \& Trondal, 2011; Lord, 2011; COM(2015) 179 final). In the expert group system of the EU, the participation of civil servants as formal members or permanent observers is pronounced, and this links these bodies up to governmental influence (Egeberg, Schaefer \& Trondal, 2003; Gornitzka \& Krick, 2018; see also Christensen \& Hesstvedt, this issue; Krick, this issue).

\section{Parliamentary and public scrutiny}

A range of expert bodies are scrutinised and appraised by parliamentary bodies. Parliaments debate and pass legislation that is drafted on the basis of advisory committee suggestions. They provide an accountability forum that scrutinises agencies (Curtin, 2007, p. 536). Members of parliaments and party groups use or contest arguments by executive and regulatory agencies as part of their own political agenda (see Rosen \& Tørnblad, this issue). Parliaments play a distinct role in the establishment and operation of expert bodies when they (co-)decide on the setup of agencies, the competencies of central banks or expert committee membership (see Curtin 2007; Landwehr \& Wood, this issue; Lord, this issue; Kelemen, 2002). Parliaments often have the right to address executive expert bodies with questions and nominate or delegate members of these bodies' management boards.

The European Parliament (EP) has recently strengthened its oversight rights towards several types of expert bodies. It has repeatedly used its budgetary powers to call for a more balanced and transparent expert group and comitology system and the Commission reacted to this by continually widening access to information on the expert group system (Holst \& Moodie, 2015; see also European Commission 2016a/b). All documents submitted to comitology committees are now 
simultaneously disclosed to the EP (and the Council). The EP has also asserted itself as the main monitoring institution of the ECB's bearings (see Curtin, 2007; Lord, this issue). Interaction between the two institutions has clearly intensified over the last years with the EP now evaluating the ECB's activities in an annual report, organising hearings with the ECB every quarter, addressing oral and written questions to the ECB president and consulting in appointment procedures to the executive board (Curtin 2017). ${ }^{7}$ Yet, since the financial crisis, the ECB's tasks have been widened considerably and the evolving accountability relationship between EP and ECB does not yet live up to the ECB's new powers and their distributive implications (Curtin, 2017, p. 32). The EP has also considerably strengthened its role in supervising agencies and is now a key actor in oversight, design and governance structures of agencies (Curtin, 2007, 2017; Lord, 2011). It adopts a multiple principalsperspective and yields some supervision tasks to the Court of Auditors, the European Court of Justice and the European Ombudsman (Lord, 2011).

A comparable development can be described for public scrutiny and transparency procedures. The amount of details that expert groups and comitology committees need to disclose about membership, agendas and activities on specific websites and through public registers has continually grown. ${ }^{8}$ Both regulatory agencies and the ECB have also strengthened efforts to explain their policies to the public. Agencies aim at ensuring transparency by means of making their websites as multilingual and

7 This is not to say that the ECB is sufficiently held to account from a perspective of democratic legitimacy. This is another, and contested, issue that is beyond the scope of this article.

8 Compare expert groups from the early days to latest entries in terms of the data provided: http://ec.europa.eu/transparency/regexpert/index.cfm?do=transparency.showList. 
accessible as possible or by coordinating with relevant interests in specific working groups (Parliament, Council and Commission, 2012, p. 14). While still keeping up a pronounced confidentiality regime (Curtin, 2017, pp. 35-40), the original secrecy of the ECB's activities has been moderated somewhat since its establishment. The ECB addresses the public with an Economic Bulletin, weekly financial statements, the ECB's annual report and regular press conferences and it thereby exceeds the formal reporting requirements (Curtin, 2017, p. 34; see also ECB, 2018).

\section{Ways of assessing the socio-political ties of expert bodies}

How should we approach the socio-political ties of expert bodies from a normative perspective? A main role for social science is to map, interpret and explain observed features and outcomes. However, research questions in the social sciences are often motivated by normative concerns, and different phases of the investigatory process often take colour from normative assumptions and value premises (Douglas, 2009). Many social scientists also contribute with institutional criticism, policy assessments and reform suggestions, and this also applies to our study, which not only asks what currently characterises the socio-political ties of expert bodies, but also whether and how expert bodies in European policy-making could be institutionalised in better ways.

Social scientists pursue different strategies when they approach the normative aspects of their inquiries (Peters, 1991). An empiricist strategy seeks recourse to methodological rigour to minimise influence from normative considerations. However, when our aim is to review institutional practices and to suggest reforms, we inevitably involve ourselves in making claims, not only about the state of affairs, but also about what ought to be, and therefore empiricism cannot be the full answer. 
Another, pragmatic strategy is to focus on how a policy or an organisation fairs from the perspective of goals and parameters that are expressed de jure or de facto. We could easily see this as a strategy for our endeavour here. For example, European agencies, expert groups and the ECB are all regulated by legislation and guidelines stating requirements that these expert bodies could be measured up against, and these requirements are utilised, but also contested and criticised within these bodies, by other institutions, or in the public sphere. To be sure, a pragmatic strategy that relies on empirically articulated standards and critiques can be promising. Yet, it can also be insufficient, since goals and parameters as we find them articulated or assumed in regulations or public debates, for instance, may be unclear, indefensible or contradictory. Finally, not so few social scientists follow the intuitivist strategy, and base their assessments of empirical phenomena on their moral intuitions and political preferences. Social scientists may for example be inclined to assess the role of experts in EU agencies and expert groups favourably because they typically pass as experts themselves or they may be ideologically disposed to deplore the political power of elites and experts. However, our immediate intuitions and commitments about what is 'right', 'just', and 'good' may be more or less defensible after closer scrutiny, and a scholarly approach seems to require that we explicate and critically review all assumptions that affect our inquiries, including normative assumptions. The strategy we pursue here could be termed normative-analytical and seeks to draw lessons from normative theory while at the same time taking feasibility conditions and the social and political context adequately into account. It is the key task of normative political theory to explicate, discuss and assess the normative claims and assumptions of political life. Principles, distinctions and considerations developed in such theory have thus a central role to play in assessments of political 
institutions and policies. However, normative political theory has recently taken a, for our purposes, problematic 'utopian' or 'ideal' turn. This turn is spurred no doubt by landmark achievements (Cohen, 2008, Estlund, 2008), but has at the same time decoupled central debates in the field from policy issues and questions of institutional organisation. Critics worry that too much contemporary normative political theory turns 'ideal' and brackets real world problems. They call for normative theorising that takes existing institutions as its point of departure and discusses their reform more bottom-up (Sen, 2009, Waldron, 2016).

To be sure, such more grounded, operational normative criteria must be adequately shaped and limited by ideal requirements and considerations. We must steer away from 'value creep: allowing one's sense of what is of ultimate value to be dictated by one's perception of what is politically feasible in the near term' (Swift and White, 2008, p. 67). At the same time, our normative parameters need to speak to the existing institutional template and socio-political embedding and take into account what is reasonable and feasible, given the actors' motivations and beliefs as well as the available organisational structures and resources. One way to search for such input would be to review existing regulations and identify the expectations they inhabit. Another way would be to collect and analyse data on the involved political actors' normative judgements. In the following, we opt for a third approach and build on empirically grounded scholarship on expert bodies, including the novel contributions of this special issue, to pinpoint central normative concerns and propose institutional remedies (section 3). A decisive question is whether the normative expectations that we find expressed in empirically grounded scholarship and the ideal expectations of normative political theory differ significantly. If they do, we have a prima facie reason to believe either that the ideal expectations are far- 
fetched under real-world conditions, or that the normative expectations informed by investigations of current practices and constraints are too concessive. If the ideal and more non-ideal normative concerns and conceptualisations rather approximate one another, we have a more robust basis for proposing viable yardsticks and institutional solutions.

\section{Normative implications of the socio-political ties of expert bodies: institutional solutions across the democratic-epistemic divide}

\section{Key normative concerns within research over the legitimate role of experts}

It is not straightforward to distillate the key message from normative political theory on the legitimate role of experts and expert bodies and the normative key concerns involved. Some contributions are ideal in the ideal theory sense - a paradigmatic case is David Estlund's (2008, p. 207) argument for why an 'epistocracy of the educated' is indefensible. Other contributions are more diagnostic and discuss the role of experts and expertise in policy-making on the basis of rather ideal requirements embedded in often grandly stated empirical claims about current developments. The assessments relied on lead moreover into different directions and pinpoint trends that are fundamentally opposed: where some diagnoses assume that experts have more political power than they used to, others assume that experts' power is diminishing. Among those scholars who see 'expertisation' as the primary development (Turner, 2013), and a rising 'expertocracy', 'technocracy' or 'post democratic' rule (for example Habermas, 2015), some are highly critical. Others welcome expertisation as a precondition for rational and knowledge-based policy-making (Pettit, 2004; Sunstein, 2018). Similarly, among those who see a return of 'the people', some are optimistic about 
expertise being 'democratised' (for example Fischer, 2009), whereas others deplore a new 'tyranny of the majority' and populist 'post-truth' politics (for example Brennan, 2016). A central explanation for these diverging evaluations are the two different standards involved across contributions and the amount of importance attached to them in individual approaches. On the one hand, there is the standard of inclusion connected to democratic norms of representation and participation. Scholars who regard this standard as the exclusive or primary standard, tend to be critical towards the political power of experts. On the other hand, there is the outcome-oriented standard emphasising the extent to which decisions and policies are rational and knowledge-based (see also Rothstein, this issue). Scholars who regard this standard as decisive tend to welcome a strengthened role of expert bodies. $^{9}$

Few normative political theorists, however, deny the relevance of one of these basic standards altogether, and in recent scholarship we find attempts to outline frameworks that take this double challenge more adequately into account. The proposal by Parkinson \& Mansbridge (2012, p. 11-12), for instance, conceptualises polities as 'deliberative systems' that need to fulfil three different functions: the epistemic function of ensuring 'reasonably sound decisions', the ethical function of promoting 'mutual respect among citizens' and the democratic function of promoting 'an inclusive process of collective choice'. Importantly, while all functions are equally decisive on a systems level, individual institutions need not fulfil all three functions equally well, but can compensate for each other. Other approaches stress the need to design and re-design individual expert arrangements in such a way that

9 Although this is not necessarily the case, see for example Landemore (2012). 
they ensure both a certain level of respectful interaction and participatory credentials, but in ways that do not compromise these arrangements' independence and cognitive orientation (Holst \& Molander, 2017). The double challenge and ways of dealing with it are also emphasised by many of the contributions to this special issue (see Krick; Landwehr \& Wood; Lord; Rothstein, this issue) and these questions are also clearly reflected in empirically grounded research on the legitimate role of the expert in democracies from the fields of public administration and the sociology of knowledge (see e.g. Busuioc, 2009; Curtin, 2007; Haas, 2004; Jasanoff, 2005; Lentsch \& Weingart, 2011; Liberatore \& Funtowicz, 2003; Nowotny, 2001). There is thus, as will become clearer in this section, a promising proximity between ideal requirements, as normative political theorists would have them, and central approaches and recommendations in our selected branches of theory-led empirical scholarship on expertise, policy advice and expert bodies. All these contributions consider both democratic and epistemic concerns as vital, and search for institutional solutions that handle this divide in a better way. In the following, we show what this more concretely amounts to. Inspired by the debates outlined above, we identify modes of dealing with the epistemic-democratic dilemma by asking to what extent expert bodies can be democratised without jeopardising the epistemic quality of their output. The challenge is to strike a balance between epistemic and democratic quality criteria that steers clear of ignoring or undermining epistemic performance (Parkinson \& Mansbridge,2012), of creating an insurmountable dilemma between accountability and independence (Busuioc, 2009) or blindly embracing any kind of societal participation as particularly democratic (Biegelbauer \& Hansen, 2011). We explore this, first, from the organisational viewpoint of public administration, which looks at socio-political ties as possible accountability forums 
and asks under which conditions they do not undermine an expert body's autonomy (e.g. Busuioc, 2009; Carpenter, 2010; Curtin, 2007; Kelemen, 2002). The second perspective we take looks at the actor level and builds on the sociology of knowledge, science studies, and social epistemology. These approaches find solutions to the democratic-epistemic divide in expert recruitment procedures that pluralise the knowledge base and limit expert biases (e.g. Haas, 2004; Holst \& Molander, 2017; Lentsch \& Weingart, 2011; Nowotny, 2001).

\section{Autonomy and accountability of the expert body}

In public administration research, the independence of an expert body essentially lies in its organisational autonomy from the 'parent body'. Organisational or bureaucratic autonomy is a source of discretion as it frees the expert body from the constraints of external interference (Verhoest, Guy Peters, Bouckaert \& Verschuere, 2004). Organisational autonomy is generally seen as a resource of an organisation's reputation and credibility that enhances its performance (Busuioc, 2009; Carpenter, 2010; Curtin, 2007; Ennser-Jedenastik, 2015; Thatcher/\& Stone Sweet, 2002). Yet, depoliticised, detached expert institutions with official (or de facto) authority suffer from serious accountability deficits (Busuioc, 2009; Curtin, 2017) and they are not always equipped to deliver the needed policy-relevant expertise (Haas, 2004; Krick, 2015). However, and this is the predicament, since their efficiency relies partly on their autonomy, their independence can sustain damage when they are closely tied to societal and political agents, when access to these venues is widened and control by elected bodies is strengthened.

Accountability can be achieved within a variety of accountability forums and through a range of control or accountability measures, but some of them interfere 
more with the autonomy of expert bodies than others. Rather problematic are procedures that include stakeholders and politicians on a par with non-political experts or that emphasise close and direct control of expert bodies' activities. Such 'ongoing policy control' mechanisms (Busuioc, 2009) will restrict or eliminate the agent's discretion, they can substantially weaken the authority of expert bodies' output and thus their raison d'être (Curtin, 2007). More suitable for striking a balance between autonomy and accountability are forms of scrutiny that are conducted ex post or ex ante. Ex ante, a principal can influence the creation of an expert body and the appointment of experts (Curtin, 2007) or constrain the agent by enacting detailed administrative procedures and deadlines (Kelemen, 2002). Societal stakeholders can provide ex ante input within loosely attached consultation structures (hearings, stakeholder forums etc.). Ex post, accountability forums can make use of institutional checks and balances as well as monitoring and reporting requirements. Budgetary powers of a principal can be used to press for changes in conduct (see Curtin, 2007; Lord, 2011 for the case of the EP) and direct principals can be assisted in 'fire-alarm monitoring' (Kelemen, 2002, p. 109) by third parties, such as courts, independent commissions, ombudsmen and public interest groups (Lord, 2011). A key requirement of ex post monitoring is transparency in terms of access to information about the expert bodies' bearings (in the form of easily accessible statistics, lists, registers and databases). Another condition of transparency and meaningful oversight are public debate and deliberation fora, where experts can be questioned and explain themselves (Curtin, 2007, p. 534). 


\section{Limited partiality and pluralisation of experts}

Apart from these institutionalised socio-political ties, which can, under the conditions specified above, function as accountability forums and help to democratise expertise without compromising the independence of expert judgments, we can identify further modes of dealing with the epistemic-democratic divide in modern governance. In the approaches we consider in the following, the procedures of recruiting and empowering experts are the key institutional parameters for reconciling epistemic with democratic demands.

From an epistemological perspective on the policy process, the independence of expert judgment lies in impartiality or absence of biases (Goldman, 2001, p. 105; Jasanoff, 2005; Lane, 2014, p. 105; see also table 1). One source of bias are conflicts of interests that follow from an expert's financial stakes or political interests in a matter (Holst \& Molander, 2017; Lane, 2014; Lentsch \& Weingart, 2011). Others are personal prejudices, but also 'group think' that can manifest itself when the staff or participation structure of an expert body is imbalanced or narrow (Goldman, 2001; Haas, 2004; Holst \& Molander, 2017). While the idea of a fully 'detached knower' may reflect untenable 'purity ideals' of knowledge (Jasanoff, 2005, p. 221) and while we can furthermore neither expect nor want fully independent policy experts that are devoid of all association and separated from all secular questions, a minimisation of expert biases and conflicts of interests increases the likelihood of impartial decisions and is a resource of trustworthiness, reliability and fairness of expert judgement (Haas, 2004; Lane, 2014, Lentsch\& Weingart, 2011). Institutions that can help to ensure a selection of competent experts who seek to make largely disinterested judgments based on facts, not emotions or personal interests, are recruitment structures that are merit-based, not political (Haas, 2004; Lentsch \& 
Weingart, 2011; see also Rothstein, this issue). Merits in this context refer to specialised knowledge and experience vis-à-vis a certain issue, sector or task. A strategy for minimising conflicts of interests can moreover build on 'organised scepticism' that requires self-declarations from aspiring staff and involves routine screenings for financial stakes and political affiliations (Lentsch \& Weingart, 2011, p. 361).

Table 1. Balancing democratic and epistemic claims on expertise

\begin{tabular}{|c|c|c|c|}
\hline & $\begin{array}{l}\text { Requisites of } \\
\text { democratised } \\
\text { expertise }\end{array}$ & $\begin{array}{l}\text { Requisites of } \\
\text { independent } \\
\text { expertise }\end{array}$ & Institutional solutions \\
\hline $\begin{array}{l}\text { Organisational } \\
\text { level }\end{array}$ & $\begin{array}{l}\text { Accountability } \\
\text { procedures that do not } \\
\text { allow direct } \\
\text { interference }\end{array}$ & $\begin{array}{l}\text { Relatively autonomous, } \\
\text { but not fully detached } \\
\text { expert organisations }\end{array}$ & $\begin{array}{l}\text { Ex ante input through } \\
\text { loosely attached } \\
\text { consultation channels } \\
\text { Administrative } \\
\text { constraints through } \\
\text { codes of conduct or } \\
\text { deadlines } \\
\text { Ex post data access and } \\
\text { transparent monitoring } \\
\text { procedures } \\
\text { Public account-giving } \\
\text { and justification fora for } \\
\text { experts }\end{array}$ \\
\hline Expert level & $\begin{array}{l}\text { Pluralisation of the } \\
\text { knowledge base that } \\
\text { avoid partiality }\end{array}$ & $\begin{array}{l}\text { Fairly unbiased, but not } \\
\text { fully detached experts }\end{array}$ & $\begin{array}{l}\text { Merit-based } \\
\text { recruitment rules } \\
\text { Staff self-declarations } \\
\text { and routine screenings } \\
\text { of conflicts of interests } \\
\text { Balance of involved } \\
\text { societal viewpoints } \\
\text { Restricted decision } \\
\text { rights for societal } \\
\text { representatives }\end{array}$ \\
\hline
\end{tabular}

From a democratic governance perspective, the extension and diversification of expert participation patterns have been suggested as answers to the accountability deficit and the detachment of expert bodies from hierarchical control. Some 
approaches lean more towards participatory democracy, some towards deliberative models and some towards associative models. The general idea is to pluralise expertise by including non-scientists into the research that policy-related expertise is based on (Bader, 2014), by promoting cognitive and scholarly diversity amongst experts (Holst \& Molander, 2017), by encouraging interaction between experts and non-experts (Nowotny, 2001), by involving citizens into expertise-based policy development (Liberatore \& Funtowicz, 2003; Pfister \& Horvath, 2014) or acknowledging the valuable (experiential as well as professional) expertise of stakeholders (Bader, 2014; see also Nowotny, 2001).

Of course, when widening the knowledge base like this, problems of partiality and politicisation can arise. These can partly be kept in check by making stakes explicit and allowing continuous 'social monitoring' by an attentive civil society in permanent, open and transparent auditing and assessment procedures, as argued above, but also by balancing the societal viewpoints that are invited in. To compensate for power imbalances in the world of organised interests, this may call for empowerment strategies such as incentives or organisational help for public interest groups with less resources. When stakeholders or 'ordinary citizens' are involved, another key to reconciling democratic and epistemic expectations can be to include them not as staff or permanent members of expert bodies with full decision rights, but as providers of non-binding input (see Krick, this issue, for more detailed institutional suggestions to implement these considerations).

\section{Concluding remarks}

This study has focused on the empirical variations and normative implications of the socio-political ties of expert bodies such as regulatory agencies, expert 
committees and central banks. Contrary to the traditional reading of expert bodies as detached, unaccountable and depoliticised, it draws attention to the numerous institutions that link expert bodies to societal actors and elected bodies.

Although we can show that the socio-political ties of the three different kinds of expert institutions we distinguish have been strengthened on the EU level, their socio-political embedding is persistent, and not new. It has been part of the story of expert bodies all along but was concealed by a narrow focus on technocratic characteristics of expert bodies - and it certainly appears more clearly when looked at through the lens we choose.

We furthermore do not make claims about general developments across systems. However, not only is the EU a key political actor in and across Europe. Arguably, it has also been a vanguard in the development of a varied set of expert bodies, and over time innovations and trends here tend to travel.

Critics with a focus on democratic legitimacy may worry that we regard EU expert bodies as sufficiently accountable, pluralised or participatory because of the emphasis we place on the value of independent expertise and knowledge-based policies. Those who worry about the politicisation of expertise and the development of post-truth politics, by contrast, may have expected a more exclusive focus on such issues and less talk about democratisation, accountability and societal responsibilities. However, what we have argued for is a more refined normative analysis that factors in both democratic and epistemic concerns and takes recent changes on the EU level into account.

In our view, an acknowledgement of expert bodies' existing links with society demands a reflection on the danger that the independence of expert judgment gets compromised by such links. At the same time, however, we believe that socio- 
political ties can be institutionalised in ways that ensure both the adequate autonomy and integrity of expert bodies as well as sufficient degrees of accountability, inclusion and participation. In accordance with these considerations, our study does not stop short at the point of identifying and describing the tensions between epistemic and democratic demands to expert bodies - and between the independence and responsiveness of expertise more specifically. Rather, it identifies institutional modes of dealing with this dilemma that can instruct institutional design choices and contribute to debates about the legitimate role of experts in democracies.

\section{References}

Bader, V. (2014) Sciences, politics, and associative democracy: Democratizing science and expertizing democracy. Innovation: The European Journal of Social Science Research, 27(4), 420-441.

Biegelbauer, P., \& Hansen, J. (2011). Democratic theory and citizen participation: Democracy models in the evaluation of public participation in science and technology, Science and Public Policy, 38(8), 589-597.

Bouwen, P. (2004) The logic of access to the European Parliament: Business lobbying in the committee on economic and monetary affairs, Journal of Common Market Studies, 42(3), 473-496

Brennan, J. (2016) Against democracy. Princeton: Princeton University Press.

Busuioc, M. (2009) Accountability, control and independence: The case of European agencies, European Law Journal, 15(5), 599-615.

Busuioc, M. (2013). European agencies: Law and practices of accountability. Oxford: Oxford University Press.

Carpenter, D.P. (2010). Reputation and power: Organizational image and pharmaceutical regulation at the FDA. Princeton: Princeton University Press.

Christensen, J., \& Holst, C. (2017). Advisory commissions, academic expertise and democratic legitimacy: The case of Norway, Science and Public Policy, 44(6): 821833. 
Cohen, G. A. (2008). Rescuing Justice and Equality. Cambridge, MA: Harvard University Press.

Corporate Europe Observatory (2017, October 3). Corporate capture at its most extreme: $98 \%$ of ECB advisors represent industry. Retrieved from https://corporateeurope.org/pressreleases/2017/10/corporate-capture-itsmost-extreme-98-ecb-advisors-represent-industry.

Curtin, D. (2007). Holding (quasi)autonomous EU administrative actors to public account, European Law Journal, 13(4), 523-541.

Curtin, D. (2017). 'Accountable independence' of the European Central Bank: Seeing the logics of transparency, European Law Journal, 23(1-2), 28-44.

Douglas, H. (2009). Science, Policy, and the Value-Free Ideal. Pittsburgh, PA: Pittsburgh University Press.

Egeberg, M., Schaefer, G., \& Trondal, J. (2003). The many faces of EU committee governance, West European Politics, 26(3), 19-40.

Egeberg, M., \& Trondal, J. (2011). EU-level agencies: New executive centre formation or vehicles for national control?, Journal of European Public Policy, 18(6), 868887.

Ennser-Jedenastik, L. (2015). The politicization of regulatory agencies: Between partisan influence and formal independence, Journal of Public Administration Research and Theory, 26(3), 507-518.

Estlund, D. (2008). Democratic Authority: A Philosophical Framework. Princeton, NJ: Princeton University Press.

European Parliament, Council and Commission. (2012). Joint statement and common approach on EU decentralized agencies. Retrieved from https://europa.eu/european-

union/sites/europaeu/files/docs/body/joint statement and common approac h 2012 en.pdf.

European Central Bank. (2018). Accountability. Retrieved from https://www.ecb.europa.eu/ecb/orga/accountability/html/index.en.html.

European Commission. (2016a). Commission decision establishing horizontal rules on the creation and operation of Commission expert groups, C(2016)3301. Retrieved from 
http://ec.europa.eu/transparency/regexpert/PDF/C 20163301 F1 COMMISS ION DECISION EN.pdf.

European Commission. (2016b). Communication to the Commission. Framework for Commission expert groups: Horizontal rules and public register, C(2016)3300. Retrieved from http://ec.europa.eu/transparency/regexpert/PDF/C 20163301 F1 COMMISS ION DECISION EN.pdf.

Fischer, F. (2009). Democracy and expertise. Oxford: Oxford University Press

Goldman, A.I. (2001). Experts: Which ones should you trust?, Philosophy and Phenomenological Research 63(1), 85-110.

Gornitzka, Å., \& Krick, E. (2018). The expertisation of stakeholder involvement in EU policymaking. In M. Góra, C. Holst \& M. Warat (Eds.), Expertisation and democracy in Europe (pp. 51-70). London \& New York: Routledge.

Greve, C., Flinders, M., \& van Thiel, S. (1999) Quangos - what's in a name? Defining quangos from a comparative perspective, Governance, 12(2), 129-146.

Haas, P.M. (2004). When does power listen to truth? A constructivist approach to the policy process, Journal of European Public Policy 11(4), 569-592.

Habermas, J. (2015). The Lure of Technocracy. Cambridge and Malden: Polity Press.

Holst, C., \& Molander, A. (2017). Public deliberation and the fact of expertise: Making experts accountable, Social Epistemology, 31(3), 235-250.

Holst, C., and Moodie, J. R. (2015). Cynical or deliberative? An analysis of the European Commission's public communication on its use of expertise in policymaking, Politics and Governance, 3(1), 37-48.

Jasanoff, S. (2005). Judgment under siege: The three-body problem of expert legitimacy. In S. Maasen \& P. Weingart (Eds.), Democratization of expertise? Exploring novel forms of scientific advice in political decision-making (pp. 209224). Dordrecht: Springer.

Kelemen, R. D. (2002). The politics of 'Eurocratic' structure and the new European agencies, West European Politics, 25(4), 93-118.

Krick, E. (2015). Negotiated expertise in policy-making. How governments use hybrid advisory committees, Science and Public Policy 42(4), 487-500.

Landemore, H. (2012). Democratic reason: Politics, collective intelligence, and the rule of the many. Princeton, NJ: Princeton University Press. 
Lane, M. (2014). When the experts are uncertain: Scientific knowledge and the ethics of democratic judgment, Episteme, 11(1), 97-118.

Lentsch, J., \& Weingart, P. (2011). Quality control in the advisory process: Towards an institutional design for robust science advice. In J. Lentsch \& P. Weingart (Eds.) The politics of scientific advice: Institutional design for quality assurance (pp. 353-354). Cambridge: Cambridge University Press.

Liberatore, A., \& Funtowicz, S. (2003). 'Democratising' expertise, 'expertising' democracy: What does that mean, and why bother?, Science and Public Policy, 30(3), 146-150.

Lodge, M. (2008). Regulation, the regulatory state and European politics, West European Politics, 31(1/2), 280-301.

Lord, C. (2011). The European Parliament and the legitimation of agencification, Journal of European Public Policy, 18(6), 909-925.

Nowotny, H. (2001). Democratising expertise and socially robust knowledge, Science and Public Policy, 30(3), 151-156.

Parkinson, J., \& Mansbridge, J. (Eds.). (2012). Deliberative systems: Deliberative democracy at the large scale. Cambridge: Cambridge University Press.

Pérez-Durán, I. (2017). Interest group representation in the formal design of European Union agencies, Regulation and Governance. doi:10.1111/rego.12150

Peters, B. (1991). Rationalität, Recht und Gesellschaft. Frankfurt: Suhrkamp.

Pettit, P. (2004). Depoliticizing democray, Ratio Juris, 17(1), 52-65.

Pfister, T. \& Horvath, A. (2014). Reassessing expert knowledge and the politics of expertise, Innovation: The European Journal of Social Science Research, 27(4), 311-316.

Saward, M. (2010). The Representative Claim, New York: Oxford University Press.

Sen, A. (2009). The idea of justice. Cambridge, MA: Harvard University Press.

Sunstein, C.R. (2016). The most knowledgeable branch, University of Pennsylvania Law Review, 164(13), 1600-1648.

Swift, A., \& White, S. (2008) Political theory, social science, and real politics. In D. Leopold \& M. Stears (Eds.), Political theory. methods and approaches (pp. 49-69). Oxford: Oxford University Press. 
Thatcher, M., \& Sweet, A.S. (2002). Theory and practice of delegation to nonmajoritarian institutions, West European Politics 25(1), 1-22.

Turner, S. (2013). The politics of expertise. New York, NY: Routledge.

Verhoest, K., Guy Peters, B., Bouckaert, G., \& Verschuere, B. (2004) The study of organizational autonomy: A conceptual review, Public Administration, 24(2), 101-118.

Vibert, F. (2007). The rise of the unelected. Democracy and the new separation of powers. Cambridge: Cambridge University Press.

Waldron, J. (2016). Political Political Theory. Cambridge, MA: Harvard University Press. 